\title{
Glutamine Supplementation Effects on Reducing Inflammation in The Ileum of Acute and Chronic Diarrhea Rats Induced by Enteropathogenic Escherichia coli
}

\author{
Deddy Satriya Putra ${ }^{1, *}$, Fadil Oenzil², Eryati Darwin ${ }^{3}$, Hafni Bachtiar ${ }^{4}$, Tofrizal ${ }^{5}$ \\ ${ }^{1}$ Department of Biomedical Science, Faculty of Medicine, Universitas Andalas, Limau Manis, Pauh, Kota Padang 25163, Indonesia \\ ${ }^{2}$ Department of Biochemistry, Faculty of Medicine, Universitas Andalas, Limau Manis, Pauh, Kota Padang 25163, Indonesia \\ ${ }^{3}$ Department of Histological Science, Faculty of Medicine, Universitas Andalas, Limau Manis, Pauh, Kota Padang 25163, Indonesia \\ ${ }^{4}$ Department of Public Health, Faculty of Medicine, Universitas Andalas, Limau Manis, Pauh, Kota Padang 25163, Indonesia \\ ${ }^{5}$ Department of Pathology and Anatomy, Faculty of Medicine, Universitas Andalas, Limau Manis, Pauh, Kota Padang 25163, Indonesia \\ *Corresponding author. E-mail: dsatriyap@yahoo.com
}

Received date: Jan 6, 2020; Revised date: Aug 3, 2020; Accepted date: Aug 4, 2020

\section{Abstract}

12 ACKGROUND: Glutamine, a non-essential amino acid, is the main fuel in the gastrointestinal mucosa. It is thought to protect the intestinal mucosa against local or systemic injury from diarrhea. This study aime $d$ to determine the relationship between glutamine supplementation and ileum histopathology in acute and chronic diarrhea rats induced by enteropathogenic Escherichia coli (EPEC).

METHODS: A randomized post-test only control group design was conducted. Thirty Rattus norvegicus Wistar strain were divided into 5 groups: one negative control group, two acute, and two chronic diarrhea groups. All four diarrhea groups were induced by EPEC at a dose of $108 \mathrm{CFU} / \mathrm{mL}$. One acute and one chronic groups were supplemented with glutamine at a dose of $810 \mathrm{mg} / 200 \mathrm{~g}$ body weight for 14 days. While the other two diarrhea groups were not treated.
The intestinal histopathology of each group was assessed and the level of inflammation was classified.

RESULTS: Significant differences in inflammation levels were found among the groups $(p<0.05)$. The highest inflammation level was observed in the acute diarrhea group without glutamine supplementation. Inflammation levels of both acute and chronic diarrhea with glutamine supplementation groups were significantly lower than the inflammation levels of acute and chronic diarrhea without glutamine supplementation groups.

CONCLUSION: Supplementation of glutamine reduces the level of inflammation and leads to the histopathological improvement of the rat's ileum.

KEYWORDS: enteropathogenic Escherichia coli, glutamine, gastrointestinal tract, histopathology, ileum

Indones Biomed J. 2020; 12(3): 275-82

\section{Introduction}

Diarrhea is a condition indicated by watery consistency stools discharged more than three times per day.(1) It is one of the major causes of morbidity and mortality in children worldwide, with $98 \%$ of deaths due to diarrhea occurring in developing countries, including Indonesia.(2-3) The results of the 2013 Indonesian Basic Health Research showed that diarrhea was the second most common cause of toddlers' mortality in Riau Province, which is up to $17.2 \%$.(4)
A strain of Escherichia coli that can cause diarrhea, especially in children in developing countries, is the enteropathogenic E. coli (EPEC).(5-6) The mechanism of EPEC causing diarrhea starts with the process of attaching and effacing; the pathogen attaches to the intestinal epithelial cells, destroys the effaces microvilli, and produces lesions. EPEC can damage the cytoskeletal border under the microvillar membrane and triggers the proliferation of actin filaments. In severe infections, it can destroy the absorption membrane of the intestinal surface and cause villous atrophy and thinning of mucous membranes. As a result, 
the damaged epithelial structure results in the decreased absorptive capacity of the intestinal mucosa and the loss of tight junction integrity that leads to the reduced epithelial resistance, increased membrane permeability, disruption of the $\mathrm{Na}^{+} / \mathrm{K}^{+}$pump, the inhibition of water and electrolyte absorption, and eventually leading to diarrhea.(7) The inflammation due to EPEC infection damages the small intestine's histopathology.(7) In previous studies, histological changes in the small intestine were found in both acute and chronic cases of diarrhea. The degree of inflammation and mucosal damage is used in the diagnosis of diarrhea and the evaluation of therapy.(8-9)

Glutamine is a non-essentialamino acid, with abundant amounts in the human body. In the gastrointestinal tract, glutamine is known as the mainfuel of the intestinal mucosa that triggers the enterocyte growth, increases intestinal barrier function and blood circulation to the intestine, plays an important role in the synthesis of nucleicand amino acids in the intestinal barrier, maintains the integrity of the tight junction, and acts as an immunomodulator.(10)

The benefits of glutamine in managing diarrhea have been observed in several studies. Glutaminehas a protective function in mucosal barriers becalse of its role in maintaining the integrity of intestinal epithelial tight junction cells. (11-13) In addition, glutamine also facilitates the enteral absorption of nutrients and electrolytes during diarrhea and reduce the severity of diarrhea by increasing water and salt uptake.(14) Glutamine can maintain the intracellular redox status and regulate several genes expression associated with various signaling pathways. Therefore, glutamine supplementation can promote enterocyte survival and proliferation, improve intestinal growth, and regulate the intestinal barrier function during injury, infection, stress, and catabolic conditions.(15) Previous studies have shown that glutamine can repair ileal microvilli in malnourished rats. Besides, glutamine is associated with the increase of intestinal enzyme activity, i.e., sucrose, maltase, and lactase, as well as with the increase of proteins spectrin and clathrin. These pieces of evidence support the view that glutamine is beneficial for intestinal repair.(16) Furthermore, glutamine promotes intestinal repair in the Wistar strain of Rattus norvegicus with chronic diarrhea.(17) However , there is still much debate about the importance of glutamine supplementation as adjuvant therapy for preventing chronic diarrhea.

Treatment of diarrhea in children from decade to decade continues to experience changes. These changes aim to shorten the duration of diarrhea and reduce mortality due to dehydration. The diarrhea prevention and eradication program are not only directed to change the behavior environment, but also strengthen the immune system of sufferers. Glutamine supplementation has proven potential, but more research is needed. Hence, our study aimed to determine the effect of glutamine supplementation on ileal histopathology in rats with acute or chronic diarrhea induced by EPEC.

\section{Methods}

A randomized post-test only control group design was conducted. Ethical approval for the study was obtained from the Faculty of Medicine, Universitas Riau (No. 15.3/ UN19.5.1.1.8/UEPKK/2018).

\section{Experimental Samples}

The study sample consisted of 30 male rats ( $R$. norvegicus, Wistar strain) aged 10-16 weeks, with body weight (BW) of 160-250 grams. The sample size was determined according to Federer's formula.(19) Samples were divided into five groups with six rats per group: negative control group (Control); acute diarrhea group (A); acute diarrhea group supplemented with glutamine (Kyowa Hakko Bio Co, Tokyo, Japan) at a dose of $810 \mathrm{mg} / 200 \mathrm{~g} \mathrm{BW} /$ day (B); chronic diarrhea group (C); and chronic diarrhea group supplemented with glutamine at a dose of $810 \mathrm{mg} / 200 \mathrm{~g}$ BW/day (D). The glutamine dose was based on the humanto-animal dose conversion factor which is $0.018 \mathrm{mg}$ /day for a rat according to the dose for a $70 \mathrm{~kg}$ human, which is 45 gr/day

\section{Animal Handling}

Sample rats were placed in plastic cages with a lid made of ram wire and lined with a filter paper mat to observe feces. The base was replaced three times a week. The cage was placed in a well-ventilated room with good air circulation. The cage environment was not humid and was maintainedat a temperature based on room temperature $\left(20-26^{\circ} \mathrm{C}\right)$, with a $12 \mathrm{~h}$ light-dark cycle. Each rat was placed in a different cage, given food and drink ad libitum, and its health was monitored every day.

\section{Establishment of The Rat Model}

Acute diarrhea was induced in groups A and B using $2 \mathrm{~mL}$ EPEC with $108 \mathrm{CFU} / \mathrm{mL}$ concentration. Chronic diarrhea was induced in groups $\mathrm{C}$ and $\mathrm{D}$ using the same dose with groups A and B but repeated every 3 days until diarrhea lasts 14 days. 


\section{Experimental Method}

Diarrheic rats of $\mathrm{A}$ and $\mathrm{C}$ groups were given the standard feed, while diarrheic rats of groups B were supplemented with glutamine for 14 days using a feeding tube at a dose of $810 \mathrm{mg} / 200 \mathrm{~g} \mathrm{BW/day}$ one day after diagnosed with acute diarrhea. In group D, glutamin e supplementation started after 14 days of standard feeding, using a feeding tube at a dose of $810 \mathrm{mg} / 200 \mathrm{~g} \mathrm{BW} /$ day, dissolved in up to $4 \mathrm{~mL}$ of water, for 14 days. After that, the rats were terminated, and ileal tissue samples were prepared. Ileum samples were taken at a point $15 \mathrm{~mm}$ proximal to the cecum and at a point $10-15 \mathrm{~mm}$ in the terminal ileum. The ileum was cut to form a sheet and clamped on to thick plastic, and then fixed in $10 \%$ formalin for 24 hours.

\section{Histological Preparation}

The fixed ileum tissue was inserted into the tissue cassettes, and tissue processing was performed by dehydration, clearing, and paraffination. After processing, tissue was sectioned, stained with hematoxylin and eosin, and mounted.

\section{Histopathological Examination}

Prepared ileum tissue was examined microscopically to determine the degree of small intestine epithelial mucosal inflammation using the Barthel scoring method.(20) Histopathological examination was carried out with an Olympus BX51 microscope (Olympus, Melville, New York, USA) at 400× magnification. The Barthel score for each category was summed and grouped as 0 for normal intestine with no signs of inflammation, 1-2 for minimal inflammation, 3-4 for mild, 5-8 for moderate, and 9-13 for severe inflammation.

\section{Statistical Analysis}

Statistical analysis was performed with SPSS version 19 (IBM Cooperation, Armonk, New York, USA). The effect of glutamine on the level of intestinal inflammation in each group was tested with the chi-squared test with a confidence level of 0.05 .

\section{Results}

The result of ileum inflammation assessment based on the Barthel score was shown in Table 1. At the third week of the study, one rat from group $\mathrm{C}$ and one rat from group $\mathrm{D}$ were died. Hence the study continued with five rats in group $\mathrm{C}$ and group $\mathrm{D}$. The control group did not show any inflammation (normal). In group A, a moderate inflammation occurred in five rats $(83.3 \%)$, and mild inflammation in one rat $(16.7 \%)$. In group B, a mild inflammation occurred in four rats (66.7\%), and one each $(16.7 \%)$ of the remaining rats showed minimal and moderate inflammation. The chisquared analysis in the levels of inflammation showed that were a significant difference in the acute diarrhea groups $(p<0.05)$. (Table 2). Based on these statistical tests, it can be concluded that there was a significant difference in the level of inflammation in rats in the acute diarrhea group, which means it was statistically proven that glutamine supplementation could reduce the inflammatory level on the intestinal histopathology of rats with acute diarrhea.

Chronic groups also showed similar results, as shown in Table 3. In group C, moderate inflammation occurred in four rats $(80 \%)$, and mild inflammation in one rat $(20 \%)$. Meanwhile, mild inflammation occurred in four rats $(80 \%)$, and moderate inflammation occurred in one rat $(20 \%)$ in group D. Results of the chi-squared test showed the significant different levels of inflammation in the chronic diarrhea group. These tests showed that it was statistically proven that glutamine supplementation could also reduce the inflammatory level on the intestinal histopathology of rats with chronic diarrhea.

Based on the histopatho logical examination, the intestinal lumen appeared to be dilated with mucosal thinning in group A compared to the control group (Figure 1 and 2). There was an improvement in mucosal thickness and reduced intestinal distension in group $\mathrm{B}$, acute diarrhea with glutamine supplementation. In Figure 3, group A showed a decrease in the number of goblet cells, accompanied by leukocyte infiltration into the lamina propria, hyperemic blood vessels, and epithelial abnormalities such as erosion or desquamation (Figure 3). In group B, an improvement in mucosal histology was found. In Figure 4, Group A with edema appeared in the submucosa of the small intestine, with hyperemic blood vessels, accompanied by leukocyte infiltration into the lamina propria. In group B, there was an improvement in the intestinal mucosa and submucosa.

In Figure 1 and 2, the intestinal lumen appeared to be dilated with mucosal thinning in group $\mathrm{C}$ compared to the control group. There was an improvement in mucosal thickness and reduced intestinal distension in group D with chronic diarrhea, which received glutamine. Also in Figure 3, group $\mathrm{C}$ showed a decrease in the number of goblet cells, accompanied by leukocyte infiltration into the lamina propria, hyperemic blood vessels, and epithelial abnormalities such as erosion when compared to the control group. Group D showed an improvement in mucosal histopathology. Group C showed edema that 
Figure 1. Assessment of histopathological feature of the ileum mucosa based on The Barthel scoring method.

\begin{tabular}{|c|c|c|c|c|c|c|c|}
\hline \multirow{2}{*}{ Group } & \multirow{2}{*}{ Sample } & \multicolumn{6}{|c|}{ Ileum Histopathology Scores } \\
\hline & & Edema & PMN & Goblet & Epitel & Total & Mean \\
\hline \multirow[t]{6}{*}{ Control } & 1 & 0 & 0 & 0 & 0 & 0 & 0 \\
\hline & 2 & 0 & 0 & 0 & 0 & 0 & \\
\hline & 3 & 0 & 0 & 0 & 0 & 0 & \\
\hline & 4 & 0 & 0 & 0 & 0 & 0 & \\
\hline & 5 & 0 & 0 & 0 & 0 & 0 & \\
\hline & 6 & 0 & 0 & 0 & 0 & 0 & \\
\hline \multirow[t]{6}{*}{ A } & 1 & 1 & 1 & 1 & 1 & 4 & 7.0 \\
\hline & 2 & 3 & 1 & 2 & 2 & 8 & \\
\hline & 3 & 2 & 1 & 2 & 2 & 7 & \\
\hline & 4 & 2 & 2 & 2 & 2 & 8 & \\
\hline & 5 & 2 & 2 & 2 & 2 & 8 & \\
\hline & 6 & 2 & 2 & 2 & 1 & 7 & \\
\hline \multirow[t]{6}{*}{ B } & 1 & 1 & 0 & 1 & 1 & 3 & 3.2 \\
\hline & 2 & 1 & 1 & 1 & 2 & 5 & \\
\hline & 3 & 1 & 0 & 1 & 1 & 3 & \\
\hline & 4 & 1 & 1 & 1 & 1 & 4 & \\
\hline & 5 & 1 & 0 & 0 & 0 & 1 & \\
\hline & 6 & 1 & 0 & 1 & 1 & 3 & \\
\hline \multirow[t]{5}{*}{$\mathrm{C}$} & 1 & 2 & 1 & 1 & 3 & 7 & 5.6 \\
\hline & 2 & 2 & 1 & 1 & 2 & 6 & \\
\hline & 3 & 1 & 1 & 1 & 2 & 5 & \\
\hline & 4 & 1 & 1 & 1 & 1 & 4 & \\
\hline & 5 & 1 & 1 & 1 & 3 & 6 & \\
\hline \multirow[t]{5}{*}{$\mathrm{D}$} & 1 & 0 & 1 & 0 & 0 & 1 & 1.8 \\
\hline & 2 & 0 & 1 & 0 & 1 & 2 & \\
\hline & 3 & 1 & 1 & 0 & 0 & 2 & \\
\hline & 4 & 0 & 1 & 0 & 0 & 1 & \\
\hline & 5 & 1 & 1 & 0 & 1 & 3 & \\
\hline
\end{tabular}

Ileum histopathology scores are based on The Barthel scoring method.

appeared mainly in the submucosa of the small intestine with hyperemic blood vessels, accompanied by leukocyte infiltration into the lamina propria (Figure 4). In comparison, in group $\mathrm{D}$, there was an improvement in the intestinal mucosa and submucosa.

\section{Discussion}

The level of inflammation of the ileum was lower in the diarrheic rats that got glutamine compared with diarrheic

Table 2. The effect of glutamine supplementation on the level of inflammation in the acute diarrhea rats.

\begin{tabular}{|c|c|c|c|c|c|c|}
\hline Group & Normal & $\begin{array}{c}\text { Minimal } \\
\text { Inflammation }\end{array}$ & $\begin{array}{c}\text { Mild } \\
\text { Inflammation }\end{array}$ & $\begin{array}{c}\text { Moderate } \\
\text { Inflammation }\end{array}$ & $\begin{array}{c}\text { Severe } \\
\text { inflammation }\end{array}$ & *p- value \\
\hline Control $(\mathrm{n}=6)$ & $6(100 \%)$ & 0 & 0 & 0 & 0 & \\
\hline$A(n=6)$ & 0 & 0 & $1(16.7 \%)$ & $5(83.3 \%)$ & 0 & 0.001 \\
\hline $\mathrm{B}(\mathrm{n}=6)$ & 0 & $1(16.7 \%)$ & $4(66.7 \%)$ & $1(16.7 \%)$ & 0 & \\
\hline
\end{tabular}

Table 3. The effect of glutamine supplementation on the level of inflammation in the chronic diarrhea rats.

\begin{tabular}{|c|c|c|c|c|c|c|}
\hline Group & Normal & $\begin{array}{c}\text { Minimal } \\
\text { Inflammation }\end{array}$ & $\begin{array}{c}\text { Mild } \\
\text { Inflammation }\end{array}$ & $\begin{array}{c}\text { Moderate } \\
\text { Inflammation }\end{array}$ & $\begin{array}{c}\text { Severe } \\
\text { inflammation }\end{array}$ & $* p$-value \\
\hline Control $(n=6)$ & $6(100 \%)$ & 0 & 0 & 0 & 0 & \\
\hline$C(n=5)$ & 0 & 0 & $1(20 \%)$ & $4(80 \%)$ & 0 & 0.001 \\
\hline$D(n=5)$ & 0 & 0 & $4(80 \%)$ & $1(20 \%)$ & 0 & \\
\hline
\end{tabular}



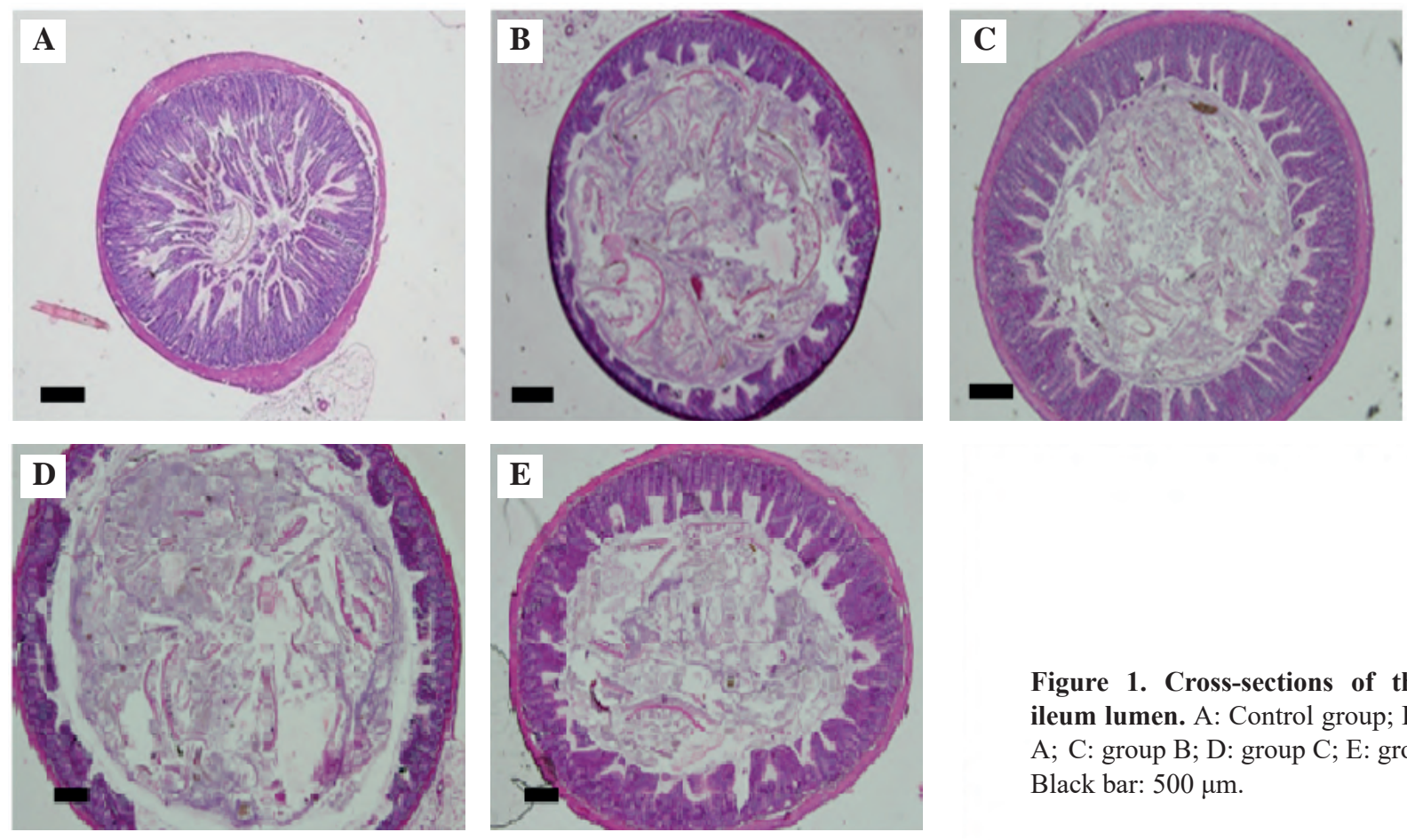

Figure 1. Cross-sections of the rat's ileum lumen. A: Control group; B: group A; C: group B; D: group C; E: group D. Black bar: $500 \mu \mathrm{m}$.

rats that did not receive glutamine. This suggests that glutamine can reduce the inflammatory reaction in the intestine in both acute and chronic diarrhea. This result is supported by a previous study that reported the reduction of inflammation and the increase of immune response in the intestine after glutamine therapy at a dose of $150 \mathrm{mg} / \mathrm{kg} /$ day for 21 days after it was induced with $15 \mathrm{mg} / \mathrm{kg}$ of cytarabine commonly used as a therapy for leukemia and lymphoma in humans.(21) Our result in the chronic group was in accordance with another study that reported the significant improvement in villus height and surface and expression of proliferating cell nuclear antigen in chronic diarrhea rats
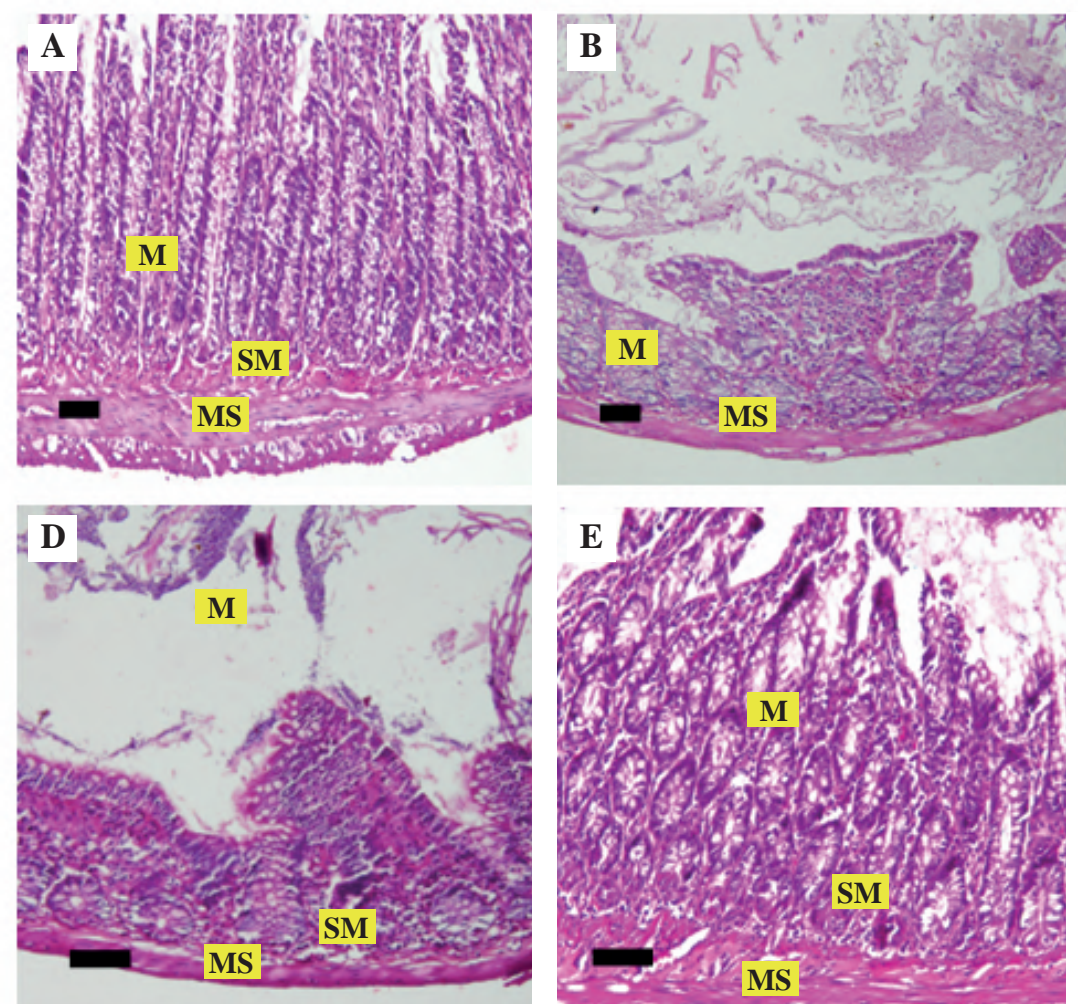

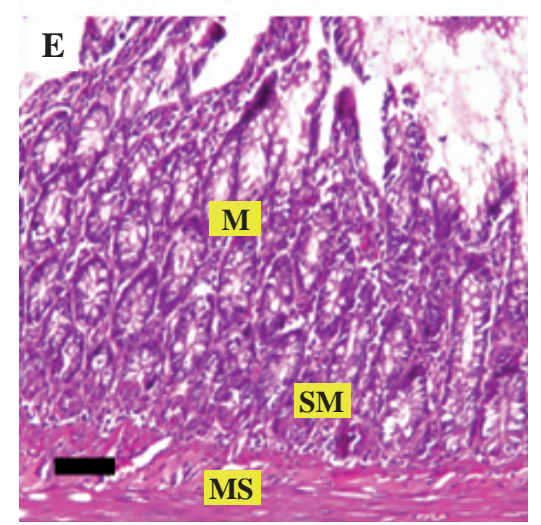

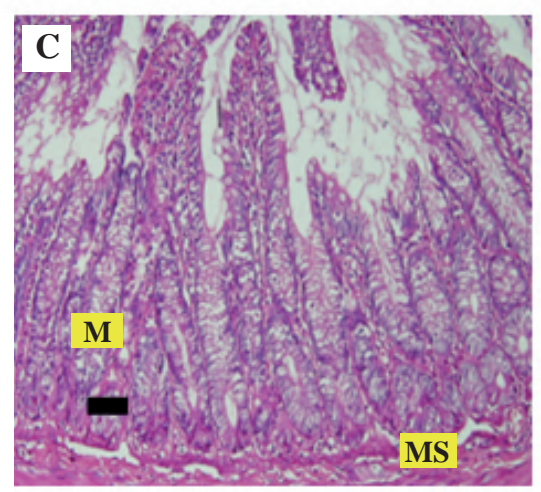

Figure 2. Sagittal section of the ileum lumen. A: Control group; B: group A; C: group B; D: group C; E: group D. M: mucosa; MS: muscularis; SM: submucosa. Black bar: $200 \mu \mathrm{m}$ 

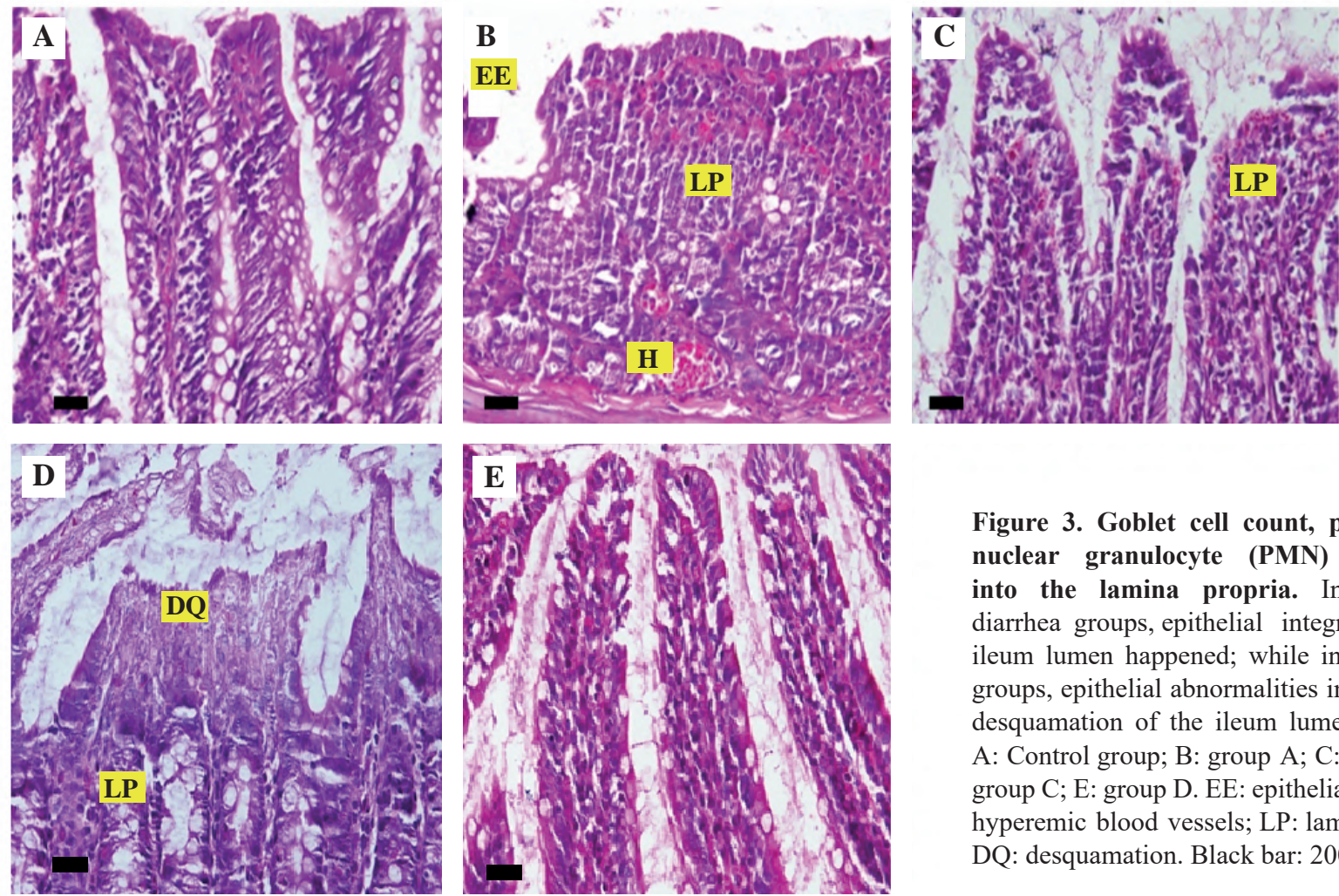

Figure 3. Goblet cell count, polymorphonuclear granulocyte (PMN) infiltration into the lamina propria. In the acute diarrhea groups, epithelial integration of the ileum lumen happened; while in the chronic groups, epithelial abnormalities in the form of desquamation of the ileum lumen happened. A: Control group; B: group A; C: group B; D: group C; E: group D. EE: epithelial erosion; H: hyperemic blood vessels; LP: lamina propria; DQ: desquamation. Black bar: $200 \mu \mathrm{m}$

after 7 days of glutamine supplementation.(17) In a doubleblind, randomized controlled trial of adult patients with chronic diarrhea in irritable bowel syndrome (IBS) showed improved intestinal permeability, as measured by urinary lactose: mannitol ratio, after the patients were given $5 \mathrm{~g}$ of glutamine three times a day. Glutamine supplementation also improved the IBS score, frequency of bowel movement, and frequency of peristalsis in the gut.(22)
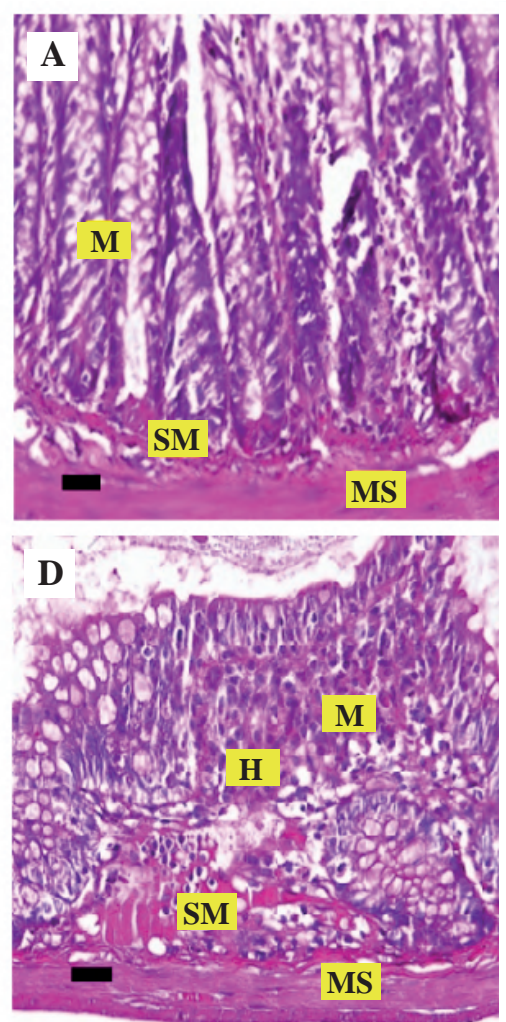
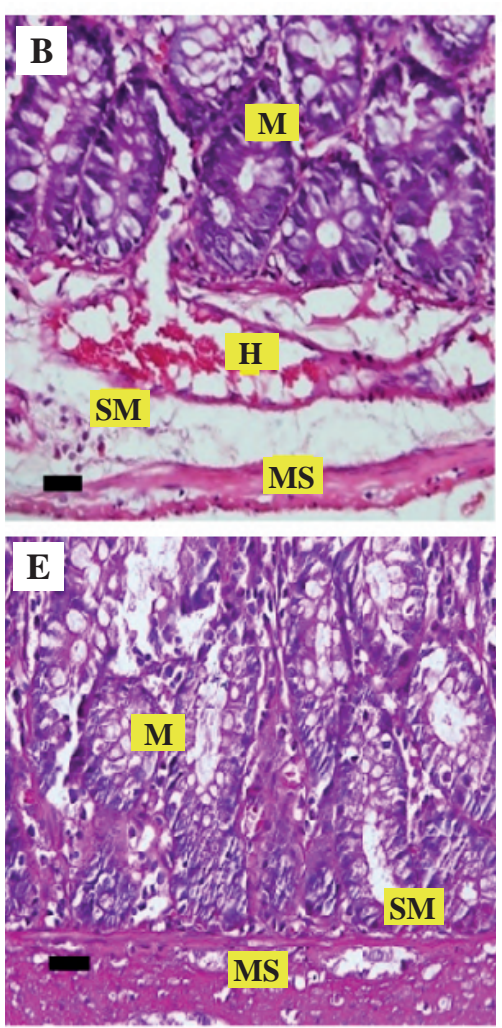

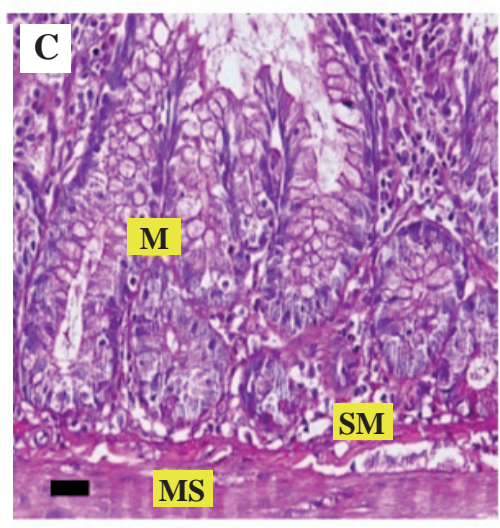

Figure 4. Edema of the ileum submucosa with hyperemic blood vessels. A: Control group; B: group A; C: group B; D: group C; E: group D. H: hyperemic blood vessels; M: mucosa; MS: muscularis; SM: submucosa of the small intestine. Black bar: $200 \mu \mathrm{m}$. 
Histopathological examination showed the improvement in every observed aspect in the groups with glutamine. These results are in line with another study that used endotoxemia-induced Wistar rats in which the group given glutamine showed improvements in intestinal histopathology (mucosal thickness, villi height, crypta depth, and intestinal wall thickness).(23) The improvement in small intestine morphology and morphometric was also observed in malnourished rats supplemented with glutamine.(24)

Furthermore, oxidative stress injury due to reactive oxygen species (ROS) can trigger the chain reactions of fat peroxidation and increase in the free radicals by oxidizing the polyunsaturated fatty acids that cause oxidative cell damage in rat's intestine. This is characterized by the production of malondialdehyde (MDA) as the final product of fat peroxidation. Glutamine supplementation was found to significantly reduce MDA.(25) This indicates that glutamine can protect rat intestines and repair tissue and cell damage mediated by ROS and intracellular antioxidant enzymes. Besides, it is also observed that the supplementation could produce a high level of tight junction proteins, including occludin, claudin, and cytoskeleton proteins.(25)

Glutamine is produced in sufficient quantities by the body, but its use tends to increase during illness, including diarrhea. This glutamine depletion leads to the interference of glutamine functions and the aggravation of the illness. Diarrhea causes intestinal mucosa damage and the glutamine deficiency inhibits its repair.(10) Enteral administration of glutamine stimulates protein synthesis in the intestinal mucosa, protects enterocytes from apoptosis, and activates immune cells. This causes glutamine to repair and maintain damaged intestinal cells.(15,27) However, without adequate levels of glutamine, damaged intestinal cells cannot be repaired effectively; therefore, glutamine supplementation is needed.(25) But further research needs to be done using various variations of the dose of glutamine and to find out the effects of glutamine used together with zinc or probiotics.

\section{Conclusion}

The supplementation of glutamine reduces the level of inflammation and leads to the histopathological improvement of the rat's ileum with acute or chronic diarrhea.

\section{References}

1. Soedarmo SSP, Garna H, Hadinegoro SRS. Buku ajar ilmu kesehatan anak: Infeksi dan penyakit tropis [Child health science textbooks: Infections and tropical diseases]. Jakarta: Ikatan Dokter Anak Indonesia; 2003.

2. Randy PP, Russell WS [Internet]. Pediatric: General medicine [update 2018 Nov 26; cited 2019 May 26]. Available from: https:// emedicine.medscape.com/article/964131-treatment.

3. Komarulzaman A, Smits J, de Jong E. Clean water, sanitation and diarrhoea in Indonesia: Effects of household and community factors. Glob. Public Health. 2017; 12: 1141-55.

4. Dinas Kesehatan Provinsi Riau. Profil Kesehatan Provinsi Riau 2012. Pekanbaru: Dinas Kesehatan Provinsi Riau; 2012.

5. Behiry I, Abada E, Ahmed E, Labeeb R. Enteropathogenic Escherichia coli associated with diarrhea in children in Cairo, Egypt. Sci World J. 2011; 11: 2613-19

6. Ochoa TJ, Contreras CA. Enteropathogenic E. coli (EPEC) infection in children. Curr Opin Infect Dis. 2011; 24: 478-83.

7. Amin LZ. Tatalaksana diare akut [Management of acute diarrhea] Cermin Dunia Kedokretan. 2015; 230: 504-7.

8. Sullivan P, Marsh MN. Small intestinal mucosal histology in the syndrome of persistent diarrhoea and malnutrition: A review. Acta Paediatr Suppl. 1992; 381: 72-7.

9. Towoliu S, Lintong P, Kairupan C. Pengaruh pemberian lactobacillus terhadap gambaran mikroskopis mukosa usus halus tikus wistar (Rattus norvegicus) yang diinfeksi dengan Escherichia coli [The effect of lactobacillus on the microscopic picture of the small intestine mucosa of the wistar rat (Rattus norvegicus) infected with Escherichia coli]. Jurnal e-Biomedik (eBM). 2013; 1: 930-9.

10. Duggan C, Gannon J, Walker WA. Protective nutrients and functional foods for the gastrointestinal tract. Am J Clin Nutr. 2002; 75: 789808.

11. Carneiro-Filho BA, Bushen OY, Brito GA, Lima AA, Guerrant RL. Glutamine analogues as adjunctive therapy for infectious diarrhea. Curr Infect Dis Rep. 2003; 5: 114-9.

12. Vicario M, Amat C, Rivero M, Moretó M, Pelegrí C. Dietary glutamine affects mucosal functions in rats with mild DSS-induced colitis. J Nutr. 2007; 137: 1931-7.

13. Rao R, Samak G. Role of glutamine in protection of intestinal epithelial tight junctions. J Epithel Biol Pharmacol. 2012; 5: 47-54.

14. Xue H, Sawyer B, Field C, Dieleman LA, Murray D, Baracos VE. Bolus oral glutamine protects rats against CPT-11-induced diarrhea and differentially activates cytoprotective mechanisms in host intestine but not tumor. J Nutr. 2008; 138: 740-6.

15. Kim MH, Kim H. The roles of glutamine in the intestine and its implication in intestinal diseases. Int J Mol Sci. 2017; 18: E1051. doi: 10.3390/ijms18051051.

16. Irawan R, Subijanto MS, Putra S, Soetjipto. Efek pemberian glutamin terhadap aktivitas sucrase, maltase, lactase dan ekspresi spectrin, clathrin dalam perbaikan mikrovili ileum pada tikus malnutrisi [Effects of glutamine administration on sucrase, maltase, lactase and spectrin, clathrin expression in repairing ileal microvilli in malnutrition rats]. Jurnal Biosains Pascasarjana. 2012; 14: 48-60.

17. Huang ZX, Ye LY, Zheng ZY, Chen XM, Ren RN, Tong GY. Effect of glutamine on small intestinal repair in weanling rats after chronic diarrhea. Zhonghua Er Ke Za Zhi. 2005; 43: 368-72.

18. Kamuchaki J, Wobodeya E, Kiguli S, Bortolussi R. Efficacy of glutamine supplementation on the outcome of children admitted 
with persistent diarrhea in Uganda: A randomized controlled study. Paediatr. Child Health. 2013; 18(1): e1. doi: 10.1093/pch/18.1.e1.

19. Federer WT. Experimental design, theory and application. New Delhi: Oxford and IBH Publ. Co; 1967.

20. Barthel M, Hapfelmeir S, Quintanilla LM, Kremer M, Rohde M, Hogardt M. Pretreatment of mice with streptomycin provides a Salmonella enterica serovar typhimurium colitis model that allows analysis of both pathogen and host. Infect Immun. 2003; 71: 2839-58.

21. Porsani MYH, Paludetti M, Orlando DR, Peconick AP, Costa RC, Oliveira LED, et al. Protective effect of $\beta$-glucan and glutamine on intestinal and immunological damage in mice induced by cytarabine (Ara-C). Pesq Vet Bras. 2017; 37: 977-83.

22. Zhou Q, Verne ML, Fields JZ, Lefante JJ, Basra S, Salameh H, Verne GN. Randomised placebo-controlled trial of dietary glutamine supplements for postinfectious irritable bowel syndrome. BMJ. 2019; 68: 996-1002.

23. Chen K, Okuma T, Okamura K, Torigoe Y, Miyauchi Y. Glutamine- supplemented parenteral nutrition improves gut mucosa integrity and function in endotoxemic rats. J. Parenter Enteral Nutr. 1994; 18: $167-71$.

24. Tannuri U, Carrazza F, Iriya K. The effects of glutamine-supplemented diet on the intestinal mucosa of the malnourished growing rat. Rev Hosp Clin. 2000; 55: 87-92.

25. Xu CL, Sun R, Qiao XJ, Xu CC, Shang XY, Niu WN. Protective effect of glutamine on intestinal injury andbacterial community in rats exposed to hypobaric hypoxiaenvironment. World J Gastroenterol. 2014; 20: 4662-74

26. Zuhl MN, Lanphere KR, Kravitz L, Mermier CM, Schneider S, Dokladny K, et al. Effects of oral glutamine supplementation on exercise-induced gastrointestinal permeability and tight junction protein expression. J Appl Physiol. 2013; 116: 183-91.

27. Pithon-Curi TC, Schumacher RI, Freitas JJ, Lagranha C, Newsholme P, Palanch AC, et al. Glutamine delays spontaneous apoptosis in neutrophils. Am J Physiol Cell Physiol. 2003; 284: C1355-61. 